\title{
Taking Local Agency Seriously: Practical Hybrids and Domestic Violence in Timor-Leste
}

\author{
Tom Kirk \\ London School of Economics and Political Science, London, U K \\ t.kirk@lse.ac.uk
}

\begin{abstract}
For many observers, state-building in Timor-Leste has overlooked and undermined local norms and governance practices, resulting in a potentially destabilising distance between citizens and the state. The emerging state justice system has been singled out for imposing inaccessible and alien institutions onto a population that has historically fought to retain its identity. Nonetheless, viewing access to justice as central to development and peace, local and international organisations continue to work to aid the equitable and swift resolution of disputes. Drawing upon qualitative fieldwork that examined a recent legal aid and paralegal programme, this article argues that some of these efforts are addressing earlier criticisms through the creation of practical hybrids; practices that use both imported and existing social norms to fulfil their clients' needs. However, the article concludes that such programmes should identify opportunities to introduce checks and balances that can further protect the vulnerable groups.
\end{abstract}

\section{Keywords}

legal empowerment - hybridity - Timor-Leste - paralegals - domestic violence justice - reconciliation

Following independence from Indonesia in 1999, Timor-Leste's constitution laid the foundations for a court system, uniform access to justice and the right 
of the accused to the assistance of a lawyer. ${ }^{1}$ These aims were initially supported by the peacekeeping troops and governance experts of the United Nations Transitional Administration in East Timor (UNTAET), a variety of bilateral and multilateral aid agencies, and domestic and international nongovernmental organisations. Together they set to the wider task of building a functioning state without any internationally recognised competing claims to authority; a position that Chopra argues gave UNTAET a form of 'statehood'.

Although politically and financially empowered, this patchwork of state builders inherited a region that had endured 25 years of occupation by Indonesia, a brief civil war in 1975, and four centuries of Portuguese colonialism. During the occupation, an estimated one third of the population was killed and local forms of political association driven underground. In its wake, state builders found few trained personnel, little infrastructure and almost no formal institutions with which to construct their ideal liberal state. Championed by Western nations, this ideal called for the state's monopoly on the use of violence, the rule of law, democracy, a market-based economy, and a bureaucracy able and willing to provide basic public goods such as security and justice.

Early observers, however, criticised Timor-Leste's state-builders for creating a highly centralised state and failing to institutionalise political participation below the national level and within rural regions. ${ }^{3}$ Furthermore it has been

1 Constitution of the Democratic Republic of Timor Leste, 20 May 2002, sections 16, 26, 38, 48, $<$ www.etan.org/etanpdf/pdf2/constfnen.pdf >, visited on 30 October 2015. Section 16 of the Constitution of the Democratic Republic of Timor-Leste states: 'All citizens are equal before the law, shall exercise the same rights and shall be subject to the same duties'. Section 26 provides: 'Access to courts is guaranteed to all for the defence of their legally protected rights and interests' and that 'Justice shall not be denied for insufficient economic means'. Section 48 provides: "Every citizen has the right to submit, individually or jointly with others, petitions, complaints and claims to organs of sovereignty or any authority for the purpose of defending his or her rights, the Constitution, the law or general interests". Section 38 also contains the provision that the accused have a right to a lawyer at all stages of proceedings.

2 J. Chopra, 'Building State Failure in East Timor', 35:5 Development and Change (2002) p. 984. It should be noted here that although no state or international body claimed sovereignty or rights over Timor-Leste (indeed Portugal had relinquished its legal claim to the territory in 1999), this does not imply that there were no local claims to authority.

3 E.g., J. Beauvais, 'Benevolent Despotism: A Critique of un State-Building in East Timor', 33 NYU Journal of International Law and Politics (2001) pp. 1101-1178; Chopra, supra note 2, p. 979-1000; T. Hohe, 'The Clash of Paradigms: International Administration and Local Political Legitimacy in East Timor', 24:3 Contemporary Southeast Asia (2002) pp. 569-589; T. Hohe and R. Nixon, United Stated Institute for Peace, Reconciling Justice: 'Traditional' Law and State Judiciary in East Timor, <www.gsdrc.org/docs/open/DS33.pdf>, visited on 30 March 2015. 
argued that they largely ignored or purposely side-lined existing local governance institutions and social norms. ${ }^{4}$ Indeed the liberal models they adopted are said to have left the state builders blind to the web of authorities and governance institutions that exist at the local level. This encouraged a belief that their efforts took place on a tabula rasa, with little need to explore how citizens engage imported notions of governance, justice or human rights. ${ }^{5}$ For many, this has created a distance between the Timorese state and its citizens that has left the young nation fragile. ${ }^{6}$

This fragility was illustrated in 2005 when protests over the perceived discrimination of Timorese soldiers from the country's western districts led to conflict between the police and army, and widespread communal violence. It is also discernible among arguments that a number of overlapping fault lines continue to threaten Timor-Leste's development and peace and indicators of widespread disenchantment with the state's delivery of public services.

Given these considerations, many suggest Timor-Leste represents a missed opportunity to forge innovative governance arrangements. ${ }^{7}$ This includes supporting actors, institutions and practices that can negotiate and accommodate imported and existing social norms. For example, it has been argued that state builders failed to prepare the population for procedural democracy by reconciling Timorese understandings of public authority that emphasise

4 E.g., O. Richmond and J. Franks, 'Liberal Peacebuilding in Timor Leste: The Emperor's New Clothes?', 15:2 International Peacekeeping (2008) pp. 185-200; A. Brown and A. Gusmao, 'Peacebuilding and Political Hybridity in East Timor', 21:1 Peace Review: A Journal of Social Justice (2009) pp. 61-69; E. Lothe and G. Peake, 'Adressing Symptoms but not Causes: Stabilisation and Humanitarian Action in Timor-Leste', 34:3 Disasters (2010) pp. 427-443.

5 V. Boege et al., 'Building Peace and Political Community in Hybrid Political Orders', 16:5 International Peacekeeping (2009) p. 607.

6 Organisation for Economic Co-operation and Development Publishing, International Engagement in Fragile States: Can't We Do Better?, <www.oecd.org/countries/somalia/ 48697077.pdf>, visited on 30 March 2015; R. Nixon, Justice and Governance in East Timor: Indigenous approaches and the 'New Subsistence State' (Routledge, Oxford, 2012); World Bank, Twenty Fragile States Make Progress on Millennium Development Goals, <www.worldbank. org/en/news/press-release/2013/05/o1/twenty-fragile-states-make-progress-on-millenniumdevelopment-goals $>$, visited on 30 March 2015.

7 Hohe and Nixon, supra note 3, p. 39; A. Brown and A. F. Gusmao, 'Peacebuilding and Political Hybridity in East Timor', 21 A Journal of Social Justice (2009) p. 63; Boege et al., supra note 5, pp. 599-615; E. Scheye, Organisation for Economic and Co-operation and Development International Network on Conflict and Fragility, State-Provided Service, Contracting Out and Non-State Networks: Justice and Security as Public and Private Goods and Services, <www.oecd .org/development/incaf/43599221.pdf>, visited on 30 March 2015. 
hierarchies, unity, balance and consensus with the win-lose outcomes inherent to elections. ${ }^{8}$ Thus many Timorese view the return of multi-party politics, which plunged the nation into civil war in 1975, as a top down imposition of values' and approach elections as a potential schism that can only be legitimately resolved through a negotiated agreement or conflict. ${ }^{9}$ Although survey evidence suggests the Timorese also value elections as a means of expressing their independence, such arguments highlight the distance between citizens and the emerging state's governance arrangements. ${ }^{10}$

Exploring one aspect of this distance, a comprehensive United Nation's report written almost a decade after independence concluded that "a large part of the population faces substantial obstacles in accessing the formal justice system', including 'barriers of awareness, cost, language and culture"." Although there are no reliable figures, it also argues that "the majority of all disputes in the country are resolved through customary law processes and alternative dispute resolution mechanisms". Nonetheless it is notable that as of 2012, Timor-Leste's formal justice system was made up of 31 Judges, 24 prosecutors and 22 public defenders for a population of almost 1.2 million. ${ }^{12}$ Together they service four district courts, the Court of Appeal and a mobile courts initiative begun in 2008. They are instructed to use Portuguese, which is spoken by

8 O. Richmond and J. Franks, 'Liberal Peacebuilding in Timor Leste: The Emperor's New Clothes?', 15:2 Peacekeeping (2008) pp. 191-194; Brown and Gusmao, supra note 4, pp. 64-65; D. Cummins and M. Leach, 'Democracy Old and New: The Interaction of Modern and Traditional Authority in East Timorese Local Government', 4:1 Asian Politics \& Policy (2012) p. 94.

9 S. Ospina and T. Hohe, Traditional Power Structures and the Community Empowerment and Local Governance Project, <info.worldbank.org/etools/docs/library/1396o8/finalreport .pdf>, visited on 30 March 2015, p. 71; Boege et al., supra note 5, p. 608.

10 E. Toome et al., Rмiт University, Melbourne, Local Perspectives on Political DecisionMaking in Timor-Leste, <mams.rmit.edu.au/2knf8my5lmow.pdf>, visited on 30 March 2015, p. 36 .

11 United Nations Integrated Mission in Timor-Leste, The Justice System of Timor-Leste: An Independent Comprehensive Needs Assessment, <www.laohamutuk.org/reports/UN/ UNMIT/JusticeNeedsAssessmentOctog.pdf $>$, visited on 30 March 2015, p. 18. While the quoted author uses the word 'customary', this paper prefers the term 'local'. Indeed terms such as 'customary' and 'traditional' are misleading as governance practices are never unchangeable or static, and always subject to flux and external influences.

12 Judicial System Monitoring Programme, Overview of the Justice Sector, <jsmp.tl/wp -content/uploads/2012/05/Overview-of-the-Justice-Sector-2012.pdf>, visited on 30 March 2015 , p. 16. 
only about 17 per cent of the population, and the majority of service users suffer from multifaceted poverty. ${ }^{13}$

According to the United States' Agency for International Development, cases that make it to court encounter a judicial system "plagued by unclear procedures in the law, unclear procedures in practice, and poor outreach and public education mechanisms".14 Furthermore, some legislation has been 'cut and pasted' by international experts from their own legal systems, without sensitivity to the Timorese context. ${ }^{15}$ Perhaps unsurprisingly, a recent survey found that 86 per cent of the population continue to view suco (village) based authorities as responsible for law and order, while just over half had heard of a court or felt able to access information on how to access one. ${ }^{16}$ Observers, therefore, have repeatedly highlighted the gulf between the reality of TimorLeste's state justice system, the ambition of its architects and the expectations of the majority of Timorese. ${ }^{17}$

Nonetheless a range of domestic and international organisations continue to implement justice reform programmes. For some, the rule of law is a way to promote economic development, check the power of abusive governments, instil democracy and enforce international human rights norms. ${ }^{18}$ Thus they

13 United Nations Development Programme, Timor-Leste: Human Development Index (HDI) Values and Ranks, <www.laohamutuk.org/econ/HDI1o/NHDRstatsEn.pdf >, visited on 30 March 2015. In 2010 Timor-Leste ranked 120 out of 169 on the global Human Development Index $(\mathrm{HDI}=0.502)$, placing it behind other East Asian and Pacific countries (with an average HDI of $\left.0.65^{\circ}\right)$.

14 United States Agency for International Development, Rule of Law in Timor-Leste, $<$ timor -leste.usaid.gov/library/evaluations $>$, visited on 30 March 2015, p. 6.

15 Ibid., p. 5 .

16 The Asia Foundation, Law and Justice in East Timor: A Survey of Citizen Awareness and Attitudes Regarding Law and Justice in East Timor, <asiafoundation.org/resources/pdfs/ TimorLesteLJSurvey2013.pdf $>$, visited on 30/03/2015, p. 20.

17 E.g., Security and Development Group, King's College, A Review of Peace Operations: A Case for Change, Conflict, <www.gsdrc.org/go/display/document/legacyid/1636>, visited on 30 March 2015; L. Grenfell, 'Promoting the Rule of Law in Timor-Leste', 9:2 Conflict, Security \& Development (2009) pp. 213-238; United Nations Development Programme, Justice System Programme, Breaking the Cycle of Violence in Timor-Leste: Access to Justice, Barriers and Decision Making Processes in the Context of Legal Pluralism, <www.tl.undp .org/content/dam/timorleste/docs/reports/DG/Domestic\%2oViolence\%20Report\%20_ with\%2ocover\%2oFINAL.pdf>, visited on 30 March 2015.

18 R. Peerenboom, 'Varieties of Rule of Law: An Introduction and Provisional Conclusion', Asian Discourse of Rule of Law (2004). Hence arguments that contemporary rule of law programming has two sides: A 'thin' emphasis on procedure and equality before the law, and a 'thick' concern for the promotion of human rights standards; For the United 
work with the judiciary and state justice institutions, support civil society's efforts to monitor these institutions, and increase the public's knowledge of and access to them. Others adopt a 'legal empowerment' approach that encompasses a broad understanding of access to justice as the ability of individuals to realise their rights and gain control over the decisions that affect their lives, including the resolution of disputes in forums considered legitimate by all concerned parties. ${ }^{19}$ This requires taking "account of the political, cultural, economic, technological and other forces that shape whether and how people can gain greater control over their lives", and engaging in initiatives that look beyond the laws, lawyers and legal institutions of the state. ${ }^{20}$ At times this may involve engaging non-state actors and institutions as vital components for contextually sensitive and needs focussed programming. Regardless of which approach they take, many of Timor-Leste's programmes tacitly suggest unresolved disputes can intensify existing fault lines and contribute to wider conflict.

This paper examines a programme that adopted an empowerment approach in Timor-Leste through the support of legal aid lawyers (LALS) and paralegals. It argued that these actors use their local knowledge and training to negotiate Timor-Leste's emerging justice system. ${ }^{21}$ In doing so they help community members to realise their rights, mitigate local power imbalances and challenge harmful social norms. Indeed, as they draw upon knowledge of both local norms and the state, legal aid lawyers and paralegals are uniquely placed to safeguard the needs of their clients and increase access to justice. While for the most part this involves working with local justice mechanisms and advising clients of the workings of the courts; in some domestic violence cases legal aid lawyers and paralegals are devising 'practical hybrids' that draw upon and blend norms and practices from both Timorese society and the liberal state's

Nations' definition and purpose of the 'Rule of Law' programming in conflict affected states see United Nations S/2004/616, Report of the Secretary-General on the Rule of Law and Transitional Justice in Conflict and Post-Conflict Societies <www.un.org/en/ ruleoflaw/>, visited on 30 March 2015.

19 S. Golub, 'Make Justice the Organizing Principle of the Rule of Law Field', 1 Hague Journal on the Rule of Law (2009) p. 63; E. Scheye, Framing Paper Produced for the World Bank Headline Seminar on Rule of Law in Conflict-Affected and Fragile Situations, Rule of Law in Fragile and Conflict Affected Countries: Working within the Interstices and Interfaces, $<$ siteresources .worldbank.org/EXTLICUS/Resources/511777-1224016350914/5474500-1257528293370/ Scheye.pdf>, visited on 30 March 2015, p. 17; L. Armytage, Reforming Justice: A Journey to Fairness in South Asia (Cambridge University Press, Cambridge, 2012) p. 125.

20 Golub, supra note 19.

21 'Justice system' indicates both state and non-state justice mechanisms. 
justice system. ${ }^{22}$ Although it will be shown that this continues a long tradition of Timorese resistance to top down and alien governance arrangements, future programmes should acknowledge and work with these strategies to identify opportunities to introduce checks and balances that further protect vulnerable groups and encourage wider rights-based discussions. Such moves would also help the state deliver on its constitutional commitments and embed its institutions within popular understandings of public authority and justice; goals that are vital to ongoing state-building efforts.

2

\section{Methodology}

The article is based on desk research and two months of fieldwork in early 2013. The latter consisted of twenty-one semi-structured interviews with the staff, and five focus groups with the clients, of three legal aid organisations; Fundacao Fatu Sinai Oecusse (FSso) in Oecusse, Fundacao Edukasaun Comunidade Matebian (FECM) in Baucau and Liberta in Dili. ${ }^{23}$ Thirteen interviews were also conducted with staff from the Asia Foundation, which managed the programme, and local and international stakeholders working on justice Timor-Leste.

Oecusse is a predominantly rural enclave in West Timor that is considered to have been somewhat less culturally affected by the last four decades of colonialism and conflict; mountainous Baucau to the East of the country contains Timor-Leste's second largest city and was a stronghold for resistance fighters during the Indonesian occupation; and Dili is the country's fast growing, centrally located, port capital. It is home to roughly 22 per cent of the population and most state institutions. The three research sites provide a spectrum of districts from rural and isolated to peri-urban and well connected. Furthermore, each has a district court.

All interviews were conducted by the author and an interpreter in a language familiar to the interviewees. For participants' protection only cases that had been resolved at least twelve months earlier were discussed and their identities have been anonymised. Care was applied during sessions to ensure participants were not re-victimised. This included halting sessions at any indication of distress or ongoing issues, resulting in a reduced number of

\footnotetext{
22 J.P.O.D. Sardan, 'Researching the Practical Norms of Real Governance in Africa'. Discussion Paper 5 , Africa, Power and Politics Programme (Overseas Development Institute, London, 2008).

23 FECM's staff also cover Los Palos, Latuem, and Manatuto.
} 
interviews. Although the paper focuses on the legal aid lawyers' and paralegals' handling of domestic violence, their work was also explored through land disputes and paternity claims.

The next section briefly explores the contemporary literature on hybridity and reviews evidence that the Timorese have long devised practical hybrids to retain their identity and institute legitimate governance arrangements in the face of oppression.

In recent years hybrid governance has emerged as a central debate in statebuilding, conflict and development studies. ${ }^{24}$ The concept's proponents focus on the interactions of societal, localised, personal or kin-based actors and institutions, with state or international actors and institutions. Given the right conditions, these interactions are argued to embed imported norms in existing governance structures, legitimise claims to public authority and institutionalise the provision of public goods.

The hybridity literature's emphasis on 'norms' reveals a culturalist approach to institutions which are seen as providing guidelines of appropriate action, backed up by sanctions (material and social) that limit non-compliance. ${ }^{25}$ Thus, depending on the observer, hybrid governance may provide social order, strengthen the states' claims to legitimacy, increase those of non-state actors, or benefit all concerned parties. However there are also suggestions that it allows the state to shirk its responsibilities, entrenches institutional pluralism and glosses over exclusionary or predatory practices; the 'dark side' of hybridity. ${ }^{26}$ Nonetheless the possibility of hybrid governance challenges the state-centric

24 E.g., A. Clunan and H. Trinkunas, Ungoverned Spaces: Alternatives to State Authority in an Era of Softened Sovereignty (Stanford University Press, Stanford, 2010); R.M. Ginty, 'Hybrid Peace: The Interaction Between Top-Down and Bottom-Up Peace', 41:4 Security Dialogue (2010) pp. 391-412; O. Richmond and A. Mitchell, Hybrid Forms of Peace From Everyday Agency to Post-Liberalism (Palgrave Macmillan, New York, 2011); K. Meagher et al., Is Academy Research, Unravelling Public Authority: Paths of Hybrid Governance in Africa, Is Academy Research, <www.wageningenur.nl/upload_mm/2/e/2/f776dıdf-43fe-4398-95a9 -11507cc115c8_RESEARCH\%2oBRIEF\%20\%2310\%2oIOB-LSE-JSRP\%2ohybrid\%20 governance\%2oin\%2oAfrica.pdf>, visited on 30 March 2015.

25 J. March and J. Olsen, ARena Centre for European Studies, Elaborating the "New Institutionalism, <www.camu.edu.pl/pdf/olsen2.pdf >, visited on 1 April 2014.

26 T. Goodfellow and S. Lindemann, 'The Clash of Institutions: Traditional Authority, Conflict and the Failure of 'Hybridity' in Buganda', 51:1 Commonwealth \& Comparative 
narratives of public goods provision, and encourages debate over alternatives to the liberal state-building projects that have dominated interventions in conflict-affected and persistently underdeveloped regions. ${ }^{27}$

With hybridity's intellectual roots in anthropology, subaltern history and legal pluralism, initial studies of the conditions that lead to hybrid governance arrangements have concentrated upon the so called 'coping strategies' of societies affected by distant, predatory, or absent states. ${ }^{28}$ They suggest that societies caught in such conditions often adapt existing norms and practices to create governance arrangements that provide public goods. For instance, local courts jointly run by clan, religious and business leaders in Somalia have been shown to draw on norms from all three spheres of activity to provide a modicum of justice where militias once dominated. ${ }^{29}$ Yet, for its proponents, hybrid governance should not be understood as the grafting together of separate actors and institutions to make new entities. ${ }^{30}$ Rather it arises from the ongoing '(re) negotiation and transformation' or 'unmaking' and 'remaking' of existing governance institutions. ${ }^{31}$

The spatial de-centring and the theoretical de-universalisation of governance that hybridity entails has led to studies at the micro, meso and macro levels. They have examined everything from the hybridised regulation of informal cross-border trade and tax collection regimes, to the state's support of localised vigilantism and international actors' governance roles in conflictaffected regions..$^{32}$ Although such arrangements do not necessarily include the poor, marginalised or vulnerable, the implication is that they can be more attuned with the population's basic needs and norms than liberal models of statehood. This can afford them a measure of legitimacy that alien or imposed

Politics (2013); K. Meagher, 'The Strength of Weak States? Non-State Security Forces and Hybrid Governance in Africa', 43:5 Development and Change (2012) pp. 1073-1074.

27 For a good introduction to the fragile states literature see J.D. John, 'Conceptualising the Causes and Consequences of Failed States: A Critical Review of the Literature', 2:25 London School of Economics Crisis States Research Centre Working Paper (2008).

28 K. Hoffman and T. Kirk, 'Public Authority and the Provision of Public Goods in ConflictAffected and Transitioning Regions', London School of Economics Justice and Security Research Programme Paper 7 (2013) p. 20.

29 K. Menkhaus, 'Governance Without Government in Somalia: Spoilers, State Building, and the Politics of Coping', 31:3 International Security (2006-2007) pp. 74-06.

30 R.M. Ginty, International Peacebuilding and Local Resistance: Hybrid Forms of Peace (Palgrave Macmillan, Basingstoke, 2011) p. 8.

31 R. Mallett, 'Beyond Failed States and Ungoverned Spaces: Hybrid Political Orders in the Post-Conflict Landscape', 15 eSharp (2010) pp. 65-91.

32 For an overview of this literature see Hoffman and Kirk, supra note 28, pp. 9-10. 
institutions may struggle to attain. Nonetheless, analysts must also ask whose interests hybrid governance arrangements serve. ${ }^{33}$

Many observers suggest that the Timorese have long used hybrid governance arrangements to cope with colonisation, occupation and, in more recent years, liberal state-building. Beginning with Portuguese attempts to co-opt liurai (local hereditary rulers) during the colonial era, studies depict the suco and uma lulik (sacred houses) as the main sites from which the Timorese have met, resisted and adapted to alien and oppressive administrations. For example, under pressure from the Portuguese some sucos created the position 'white liurai' alongside that of the original 'black liurai'. The former became responsible for negotiations with the colonial administration, including tax collections, while the latter continued to govern the suco according to local norms. ${ }^{34}$ Similarly studies have uncovered how communities retained their sense of identity under occupation by lobbying the Indonesians to choose indigenous administrators from those belonging to liurai bloodlines at the same time as they organised the clandestine resistance movement's command structure along kinship lines. ${ }^{35}$ Some Timorese refer to such practices as "wrapping up" the old in the new, wherein the "old" represents locally-recognised sources of authority, and the "new" represents the formal governance arrangements of the day. ${ }^{36}$

It has also been shown how in the post-independence era, some local leaders are seeking to fulfil the individualistic requirements of procedural democracy whilst maintaining local understandings of political authority that rely upon relationships to hierarchically ordered uma lulik. ${ }^{37}$ This often involves careful negotiations within communities over the need to elect leaders that come from bloodlines that are connected to the suco's founding uma lulik and are, therefore, legitimate in the eyes of the ancestors, and those that have the ability to

33 Meagher, supra note 26, pp. 1073-1074. Indeed Meagher reminds us that analysts and practitioners wishing to interpret or work with hybridity must empirically investigate each locality, carefully uncovering the institutions that enjoy legitimacy and those that mask oppression.

34 M. Tilman, 'Customary Social Order and Authority in the Contemporary East Timorese Village: Persistence and Transformation', 11 Local-Global: Identity, Security, Community (2012) p. 196.

35 Richmond and Mitchell, supra note 24, p. 108; Ospina and Hohe, supra note 9, p. 71; D. Cummins, 'A State of Hybridity: Lessons in Institutionalism from a Local Perspective', 37:1 The Fletcher Forum on World Affairs (2013) pp. 143-160.

36 Cummins, ibid., p. 143.

37 Cummins and Leach, supra note 8. A.B. Santos and E.D. Silva, 'Introduction of a Modern Democratic System and its Impact on Societies in East Timorese Traditional Culture', 11 Local-Global Journal (2012) pp. 214-218. 
secure public goods and services from the state. In some instances this requires performing ritualised ceremonies that sanction the election of those that do not fit the former criteria, but have the education and skills for the latter. Such spiritual concerns remain important enough that many sucos have begun rebuilding uma lulik destroyed during the occupation and returning sacred items to them that are believed to have helped communities survive the period's atrocities. ${ }^{38}$ Arising from a combination of the desire to have control over their everyday lives, to retain a sense of their identity and to, in some sense, legitimise imposed institutions, these practices all require creative interactions between local, kin based, spiritual norms and new modes of liberal governance.

\section{$4 \quad$ Liberal State Building and New Approaches to Local Challenges}

For those working with a hybridity lens, liberal state-building models can be counterproductive too because they ignore and even seek to repress the capacities of non-state sources of public authority. ${ }^{39}$ Indeed they are premised on an, often unstated, view of the local as a site of illiberal or undesirable practices, many of which are considered to represent temporary hang-overs from an uncivilised past. The resulting top-down engagements between liberal states and communities reduce the latter's ability to adapt and develop coping strategies that can provide essential public goods, such as justice and security. Moreover, for those interested in hybridity, recent state-building interventions serve as warnings that outsiders are unlikely to be able to fully replace local governance institutions without unintended consequences. ${ }^{40}$ This is especially so for socially fragmented, subsistence-based societies such as Timor-Leste, within which people have long functioned without the presence of a responsive state at the local level and endured a repressive one at the national. ${ }^{41}$ This is because much of the population remains tied into networks of social relations and webs of mutual obligation which 'are much more powerful than obligations as a 'citizen", causing them to put the 'rules of their group' above those of the state. ${ }^{42}$

Within the contemporary practitioner focussed hybridity literature, responses to such challenges have largely taken two forms: The first seeks to change local norms through social engineering programmes that engage local

38 Brown and Gusmao, supra note 4, pp. 66-68.

39 Ginty, supra note 24, pp. 391-412; Richmond and Mitchell, supra note 24.

$40 \quad$ Boege et al., supra note 5 .

$41 \quad$ Nixon, supra note 6.

42 Boege et al., supra note 5 . 
institutions and spread liberal values. ${ }^{43}$ This includes the use of formal laws to enforce new norms and educational programmes that challenge undesirable mind-sets. The second asks liberal institutions, including constitutions and criminal laws, to be relaxed to accommodate local social norms. ${ }^{44}$ Both approaches assume that existing norms, at least in the short term, can be positively functional, and both assume that in the long run illiberal actors and institutions can be socialised into liberal norms. ${ }^{45}$ While the first assumption runs the risk of romanticising and legitimising exclusionary, oppressive or harmful practices, the second is based on limited evidence of the trajectory of long-term processes of social change. ${ }^{46}$ Perhaps more dangerously, both approaches also suggest that interveners are best placed to develop hierarchies of norms and that they are able to lead processes of change. This, however, ignores the hybridity literature's initial focus on the bottom-up, adaptive coping strategies of populations caught in difficult circumstances.

In an attempt to address these deficiencies, emerging research is framing particularly difficult development challenges, including governance, as arising from collective action problems that should be tackled by citizens and domestic governments working together. ${ }^{47}$ Yet, rather than completely dismissing the role of outsiders, the research cites their potential to encourage and support processes of bricolage that create 'practical hybrids'. This process is conceived of strategies that combine local 'repertoires', social norms and moral economies with imported and tested governance practices. ${ }^{48}$ As these hybrid governance arrangements are refined through trial and error they may be gradually institutionalised

43 Hoffman and Kirk, supra note 28, pp. 17-25.

44 Chandler, supra note 53, pp. 27-48.

45 S. Nadarajah and D. Rampton, 'The Limits of Hybridity and the Crisis of Liberal Peace', 41 Review of International Studies (2014) pp. 49-72.

46 Meagher et al., supra note 24, p. 3.

47 M. Andrews, The Limits of Institutional Reform in Development: Changing Rules for Realistic Solutions (Cambridge University Press, New York, 2013); D. Booth, 'Aid Effectiveness: Bringing Country Ownership (and Politics) Back In', 12:5 Conflict, Security \& Development (2012); S. Unsworth, An Upside Down View of Governance (Institute of Development Studies, Brighton, 2010).

48 Booth, supra note 47, pp. 84-87; F. Cleaver et al., King's College Environment, Politics and DevelopmentWorking Paper Series, Beyond Negotiation? Real Governance, Hybrid Institutions and Pastoralism in the Usangu Plains, Tanzania, <www.kcl.ac.uk/sspp/departments/geography/research/epd/wp61Cleaver.pdf>, visited on 1 April 2015. As Cleaver et al. explain: "In French 'bricolage' means to make creative and resourceful use of whatever materials at hand, regardless of their original purpose and we use this as an analogy for the way in which people patch together institutions from existing social and institutional arrangements". 
and become part of a locally grounded form of everyday governance. This process can be supported through 'arm's length' programmes that provide local actors with opportunities to organise, remove external obstacles to change and introduce incentives that encourage experimentation. ${ }^{49}$ Outsiders are also urged to time their support to opportune moments when the legitimacy of entrenched institutions is destabilised and new leaders emerge.

Crucially these approaches are explicit about the political determinants of hybrids. ${ }^{50}$ On the one hand, they call on practitioners to abandon naive assumptions that elites and citizens in developing countries have developmental orientations. On the other, they recommend examining the historical incentive structures and legitimation strategies open to elites claiming public authority at micro, meso and macro levels. ${ }^{51}$ This includes opening up the black box of local social norms to help practitioners more accurately discern when elites, including interveners, are likely to allow institutions the freedom to adapt and address obstacles to development. In this sense, these newer approaches encourage practitioners to scour local histories to avoid the hybridity literature's tendency to romanticise local social norms and to ground programmes in local political realities.

Similarly, the emerging focus on 'resilience', defined "as the capacity to positively or successfully adapt to external problems or threats", directs attention to local responses to communal problems. ${ }^{52}$ For those interested in resilience, the 'local' or the 'everyday' is comprised of the fluid and constantly adapting micro-processes and practices of ordinary people. ${ }^{53}$ However they argue that outsiders are often unable to fully grasp the interconnections and interdependencies underlying many developmental challenges found at the community level, including poor governance. ${ }^{54}$ Thus they should examine community

49 D. Booth, Overseas Development Institute, Facilitating Development: An Arm's Length Approach to Aid, <www.odi.org.uk/sites/odi.org.uk/files/odi-assets/publications-opinionfiles/8330.pdf>, visited on 31 March 2015 .

$50 \quad$ Andrews, supra note 47, p. 51.

$51 \quad$ Unsworth, supra note 47, p. 36.

52 D. Chandler, 'Resilience and Human Security: The Post-Interventionist Paradigm', 43:3 Security Dialogue (2012) p. 217.

53 D. Chandler, 'Resilience and the 'Everyday': Beyond the Paradox of 'Liberal Peace', 41:1 Review of International Studies (2014) p. 44.

54 B. Ramalingam et al., Overseas Development Institute, Exploring the Science of Complexity: Ideas and Implications for Development and Humanitarian Efforts, <www.odi.org/sites/ odi.org.uk/files/odi-assets/publications-opinion-files/833.pdf>, visited on 31 March 2015; B. Ramalingam, Aid on the Edge of Chaos: Rethinking International Cooperation in a Complex World (Oxford University Press, New York 2013). 
members' own attempts to address their problems. Such examinations can aid the design of 'enabling interventions' that 'use cultural, communal, and informal networks to produce less problematic practices". ${ }^{55}$ In this sense, a focus on resilience is a pragmatic attempt to uncover the agency of previously marginalised actors. Alongside the approaches described above, the idea of resilience advances debates over hybridity beyond calls for social engineering or the adaption of liberal laws to local realities. Indeed it suggests many communal problems are amenable to community led solutions; directing hybridity back to its roots in creative coping strategies. In the next two sections we explore a legal aid programme that provided local actors in Timor-Leste with the tools and space to devise practical hybrids in response to domestic violence.

The Asia Foundation, a United States-based international non-governmental organisation, began its Access to Justice (ATJ) programme in Timor-Leste in 2002. In the words of one assessor, "The ATJ programme identifies and seeks to address critical unmet community justice needs, being the provision of basic legal information and greater access to state and non-state based justice processes". ${ }^{56}$ In 2008 the programme, which had been supporting legal aid lawyers, assisted two local non-governmental organisations, FECM and FSSO, to employ paralegals. ${ }^{57}$ Interviewed ATJ staff confidently argued that the state's limited capacity, a heavy reliance on non-state justice mechanisms, multifaceted poverty and the population's limited knowledge of state justice institutions provides ideal ground for lawyers and paralegals.

In their most conservative form, legal aid lawyers and paralegals provide the poor with free or affordable legal advice and give those unable or unwilling to use state legal services an alternative source of representation. While paralegals often lack the legal literacy of certified lawyers and are barred from the courts, they can provide a crucial bridge between the state's justice institutions, legal aid lawyers and communities. These functions are enhanced when paralegals are recruited from within the communities where they live and

55 Chandler, supra note 53, p. 20.

$5^{6}$ The Asia Foundation, Midterm Evaluation of Access to Justice Program (Internal Programme Document).

57 Avocats Sans Frontières, ASF's Actions in Timor-Leste, 2002-2009, <www.asf.be/wp -content/publications/ASF_Actions2002-2009_Timor.pdf>, visited on 31 March 2015. It is noted that this was not the first programme to use paralegals in Timor-Leste. 
work. ${ }^{58}$ The programme's lawyers and paralegals, however, were also encouraged to engage non-state justice providers. Thus they acted as 'mediators' for certain categories of dispute. This variously involved advising local authorities and disputants using non-state justice mechanisms, or leading the mediation of disputes themselves. ${ }^{59}$ These roles were complemented with educational programmes designed to impart basic legal knowledge, including information on citizens' rights, to community members and local authorities. ${ }^{60}$

The programme's final report suggested that the legal aid organisations mediated the vast majority of their cases (see Figure 1). ${ }^{61}$ For example, Fsso's isolated lawyers mediated 86 out of 118 cases they handled from 2009-2010 and their paralegals mediated 635 out of 640 cases from 2009-2011. For their part, FECM's lawyers mediated 9o out of 242 cases from 2009-2010, while their paralegals mediated 999 out of 1034 cases from 2009-2012. The only significant deviation from this pattern was found among Liberta's lawyers who mediated 27 out of 57 cases from 2009-2010 and, as those interviewed suggested, mediated even more of their cases from 2010-2012. This is likely explained by Liberta's concentration on women's cases, including domestic violence, which 2010's Law against Domestic Violence (LADV) made a public crime that must be pursued through the courts. ${ }^{62}$ However, despite this, the research revealed that in many instances lawyers and paralegals continued to play important roles in addressing the needs of victims of domestic violence and the eventual resolution of their cases. To understand how and why, this section briefly explores Timorese notions of justice (see Table 1).

$5^{8}$ E. Harper, 'Engaging with Customary Justice Systems', in J. Ubink (ed.), Customary Justice: Perspectives on Legal Empowerment (International Development Law Organization, Rome, 2011) p. 38. Capturing this, Harper terms such actors 'community paralegals'.

59 Ibid.

6o Here and for the remainder of the paper, the term 'local authorities' refers to community leaders such as the Chefe de Aldeia (elected hamlet head), Chefe de Suco (elected village head), Lian Nain (spiritual leader) and elders. When referring to state authorities, the prefixes 'state' or 'government' will be used. This acknowledges that community leaders are just as much authorities as state representatives.

61 M. Coghlan and S. Hayati, The Asia Foundation, Final Evaluation of Component One of the Access toJustice Program, <pdf.usaid.gov/pdf_docs/PDACWo22.pdf $>$, visited on 31 March 2015.

62 Democratic Republic of Timor-Leste: Law no. 7/2010, Law Against Domestic Violence (2010). The LADV defines it as 'any act or sequence of acts committed within a family context, with or without cohabitation, by a family member against any other member of that family ... which resulted, or may result, in physical, sexual or psychological injuries or suffering, economic abuse, including threats such as intimidating acts, bodily harm, aggression, coercion, harassment, or deprivation of freedom'. Before the LADV judges routinely prosecuted domestic violence cases as semi-public crimes which can only be charged following complaint of the victim. 


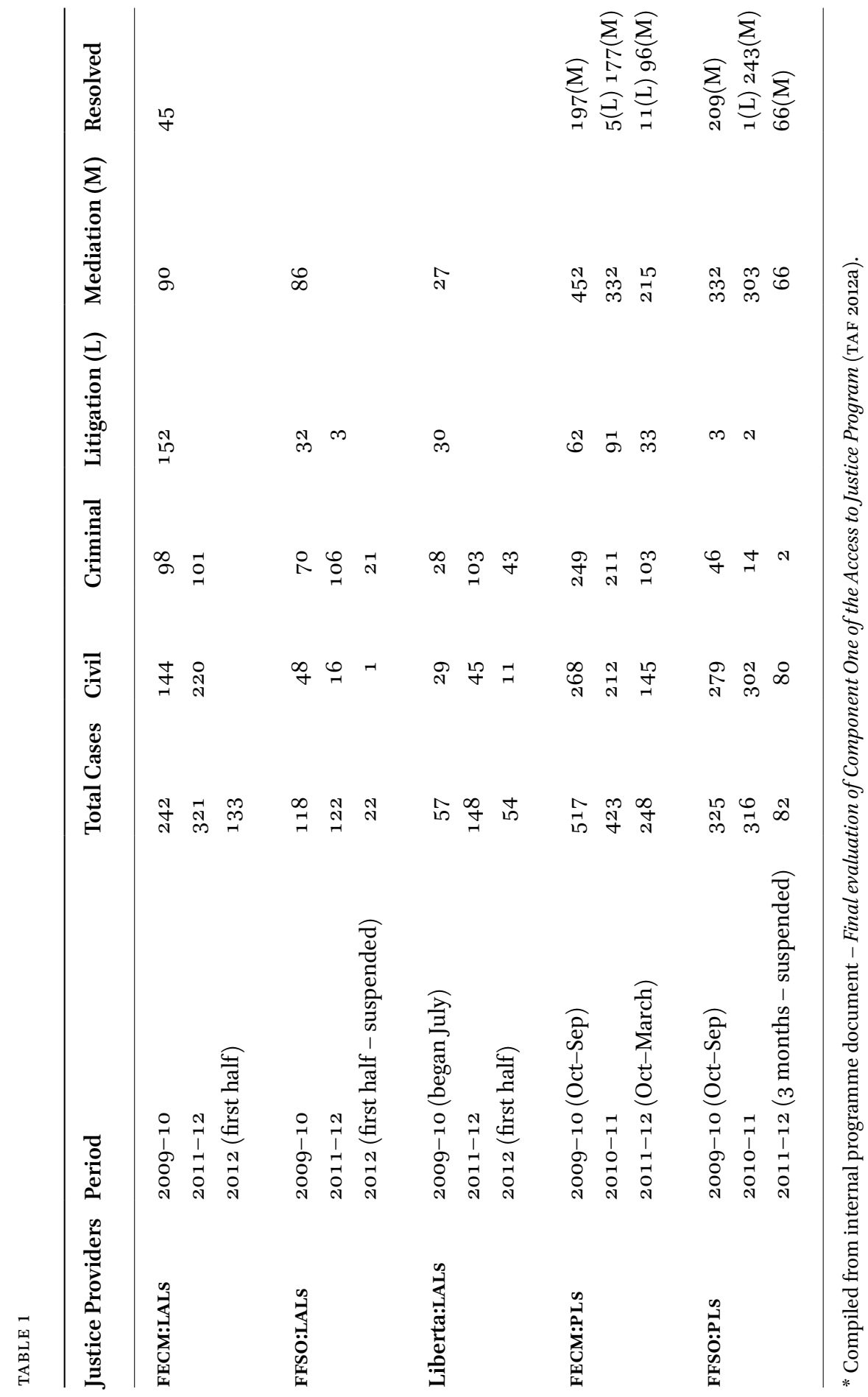


Although those interviewed often attributed the high rate of mediation to the state justice system's lack of capacity, it was also argued that the state's deficits could not account for all of the mediations. Instead the nuances of individual cases, preferences and agency of different actors, and contextual factors were all cited as potential influences on the eventual method of resolution. Indeed a survey of the legal aid organisations' clients reported that, despite having the differences between non-state and state justice processes 'clearly' explained to them, they often choose to resolve their disputes through mediation. ${ }^{63}$ Upon further questioning, participants regularly suggested disputants avoid litigation because the courts create "winners and losers", and fines or prison sentences can lead to cycles of violence between families. These findings accord with other studies that suggest reconciling the disputants' wider families and appeasing the ancestors are primary aims for local justice mechanisms. ${ }^{64}$

Within Timorese culture, reconciliation can be understood as restoring the exchange, balance and circulation of values between individuals and families. Although different values are embodied in people, especially women, and objects, the centre of Timorese's socio-cosmic lives is located in the relationship between families that give wives, 'wife-givers', and those that receive wives, 'wife-takers'. 65 When societal obligations, such as participation in customary rituals, marriage vows, and the respect for property or person, are broken, a reconciliation ceremony is required to restore the flow of values and avoid the misfortune, illness and, in the words of participants, "disunity" that accompany the displeasure of the ancestors. For most transgressions this involves the disputing parties negotiating the terms of reconciliation with the involvement of their extended families and, depending on the nature of the dispute, local authorities, including elders, the Lian Nain, Chefe de Aldiea and/ or Chefe de Suku. When successful an exchange of promises, compensation and/or gifts will take place, and a reconciliation letter will often be signed.

In accordance with this description, legal aid lawyers and paralegals suggested that they seek settlements that can peacefully reconcile parties. Two cases illustrate this: In the first, a contested plot of land was simply split between the quarrelling parties; while in the second, a squatter, citing the constitution's right to housing to justify his actions, was given compensation in

63 The Asia Foundation, Legal Aid Organisations Client Survey 2012: A Survey of Client Services by the Legal Aid Organisations (Internal Programme Document) p. 16.

64 T. Hohe, 'Justice Without Judiciary in East Timor', 3:3 Conflict, Security \& Development (2003) p. 334; D. Babo-Soares, 'Nahe biti: The Philosophy and Process of Grassroots Reconciliation (and Justice) in East Timor', 5:1 Asia Pacific Journal of Anthropology (2004) p. 4.

65 Hohe and Nixon, supra note 3, p. 39; Brown and Gusmao, supra note 4, pp. 11-16. 
return for moving out of a property. ${ }^{66}$ Although by Western values it is strange for the property owner to compensate the squatter, the legal aid lawyer that mediated the case reasoned that taking the squatter to court would create further expenses for both parties. ${ }^{67}$ Furthermore it was argued that long delays and zero-sum rulings can lead to frustrated parties committing acts of violence. Thus, given the limitations of the state's justice system and the desire to avoid bloodshed, compensating the squatter can be understood as a pragmatic solution. Summing up the apparently obvious advantages of adopting participatory, case by case and contextually sensitive approaches to land disputes, one interviewee remarked that while local justice mechanisms, legal aid lawyers and paralegals "use the clients to resolve disputes, the courts use the law".68

While it should be recognised that the exact method of reconciliation varies across Timor-Leste's diverse ethno-linguistic communities, this notion of reconciliation was generalisable across the research sites. Furthermore the interviewed legal aid lawyers and paralegals described an informal, yet strict, hierarchy of justice forums. It begins with attempts at reconciliations between disputants' families, often involving local Lian Nains; failing this cases are brought before the Chefe de Aldeia or the Chefe de Suku; and finally to the courts. ${ }^{69}$ As disputants move up the hierarchy it is usual for all those involved in the preceding step - including family members, local authorities, members of the Conselho de Suku (village council), the Polícia Nacional de Timor-Leste (PNTL), and/or local stakeholders such as representatives of women's shelters to move with them and attend subsequent attempts at reconciliation. Given the practice of paying "cigarette money" to local authorities, reconciliation ceremonies that require food and drink for all those involved, and the expense of travelling to justice forums, including missing a day's work, interviewees suggested that when given the opportunity most disputants are reluctant to skip steps. Thus 'forum shopping' does not appear to be a factor in clients' decisions over where to have their disputes resolved..$^{70}$ However, as the next section argues

66 Interview with FECM staff, 21 May 2013; interview with Liberta staff, 29 May 2013.

67 As the squatter occupied the house during the confusion of 1999's independence, it would likely have required a lengthy court case to piece together evidence against him.

68 Interview with FECM staff, 20 May 2013.

69 In some cases, particularly those involving disputes between communities or when local authorities were involved in the dispute, sub-district or district coordinators act as mediators.

70 F.V. Benda-Beckmannn and K.V. Benda-Beckmann, 'The Dynamics of Change and Continuity in Plural Legal Orders', 53:54Journal of Legal Pluralism (2006) pp. 1-44. Forum shopping' can be viewed as the practice of ignoring justice mechanisms that provide unfavourable outcomes and taking cases to alternative justice providers. 
with respect to domestic violence, these understandings of reconciliation and methods of dispute resolution have been challenged by the liberal state.

A survey from 2009-2010 found that 28 per cent of interviewed Timorese women had experienced domestic violence in the preceding twelve months and 74 per cent of those that were married claimed their partner was involved. ${ }^{71}$ Yet only 24 per cent reported incidents to authorities. Despite this low referral rate, it is notable that another survey conducted in 2008 reported that 45 per cent of police officers viewed domestic violence as the most serious problem in their community. ${ }^{72}$ In response, the young state, backed by international organisations, has used a mix of legislation, infrastructure and civil society activity to tackle domestic violence. Indeed the Law Against Domestic Violence (LADV) was followed in 2012 by the National Action Plan on Gender-Based Violence. ${ }^{73}$ Although it has been suggested such efforts are increasing the number of cases reaching the courts, there is little information on the proportion of total incidents they represent. ${ }^{74}$

Nonetheless a growing body of studies explore Timorese attitudes towards domestic violence..$^{75}$ They depict a culture in which women are often blamed for causing domestic violence, have little voice during the handling of incidents, suffer from a lack of enforcement of rulings by justice bodies, and can be

71 National Statistics Directorate Timor-Leste, Ministry of Finance Timor-Leste, and ICF Macro, Timor-Leste Demographic and Health Survey 2009-2010, <www.measuredhs.com/ pubs/pdf/FR235/FR235.pdf>, visited on 31 March 2015, p. 228.

72 L. Chinn and S. Everett, The Asia Foundation, A Survey of Community-Police Perceptions: Timor-Leste in 2008, (2008), <asiafoundation.org/resources/pdfs/SurveyofCommunity PolicePerceptions.pdf $>$, visited on 31 March 2015.

73 East Timor Law and Justice Bulletin, Adoption of the National Action Plan on Gender-Based Violence by the Council of Ministers, < easttimorlegal.blogspot.co.uk/2012/o6/adoption-of -national-action-plan-on.html>, visited on 31 March 2015.

74 Breaking the Cycle of Violence, supra note 17.

75 N. Khan and S. Hyati, Study Commissioned by Forum Komunikasi untuk Perempuan Timor-LesteLorosa'e, Bride-Price and Domestic Violence in Timor-Leste: A Comparative Study of Married-In and Married-Out Cultures in Four Districts, < countryoffice.unfpa.org/ timor-leste/?reports=6108>, visited on 1 April 2015; A. Kovar, 'Approaches to Domestic Violence Against Women in Timor-Leste: A Review and Critique', 3 Human Rights Education in Asia-Pacific (2012) pp. 207-257; Breaking the Cycle of Violence, supra note 17. 
ostracised for taking cases to state authorities. ${ }^{76}$ Furthermore, evidence suggests many women remain unaware of their rights, live in communities that place family unity above their protection and consider all but serious harm as a private matter. ${ }^{77}$ Most women are considered to be dependent on their male family members, both for their livelihoods and their voice in social arenas, including local justice mechanisms. ${ }^{78}$

Upon marriage women often exchange dependency upon their own family for a dependency on their husband and his family. Should domestic violence occur the priority of the community has traditionally been to reconcile the couple's families, thereby restoring the flow of values between them and appeasing their ancestors. In many communities this includes the payment of compensation, the exchange of gifts, and the writing up of a reconciliation letter detailing the offence and intention not to repeat it. ${ }^{79}$ However this practice has been heavily criticised as the compensation often goes to the victim's family rather than the victim herself. ${ }^{80}$

Since 2010, however, the LADV has required suco authorities and legal aid organisations to notify state authorities of domestic violence, at which point the suspect is usually detained, testimonies are collected and the incident becomes a public matter. Both interviewed legal aid organisation staff members and their clients argued that these reporting obligations prevent fears of the state's alien justice system and intimidation from preventing cases from being tried. Furthermore, it was also suggested the LADV gives staff at legal aid organisations a tool with which to challenge the widespread notion that domestic violence is a non-serious everyday, "spoon and plate", problem. ${ }^{81}$ Some claimed that this has increased space for discussions within communities about domestic violence, made local authorities aware of their obligations to report it to the state and encouraged victims to approach legal aid organisations.

76 A. Kovar, supra note 75, p. 215; A. Swaine, Report for the International Rescue Committee, Traditional Justice and Gender Based Violence, $<$ papers.ssrn.com/sol3/papers.cfm?abstract _id=1440231>, visited on 1 April 2015, p. 15; The Asia Foundation, "Ami Sei Vítima Beibeik": Looking to the Needs of Domestic Violence Victims, <asiafoundation.org/publications/ pdf/1296>, visited on 1 April 2015, p. 14.

77 The Asia Foundation, "Ami Sei Vítima Beibeik", supra note 76.

78 It should be noted that the evidence for women's dependency is anecdotal at present.

79 Breaking the Cycle of Violence, supra note 17, pp. 30-32.

8o Grenfell, supra note 17, p. 321; Hohe and Nixon, supra note 65, p. 60.

81 Interview with FECM staff, 20 May 2013. The use of the term 'spoon and plate' highlights the difficulty of introducing foreign terms such as 'domestic violence' into societies that do not attach the same connotations to the act. 
However, discussing the LADV further, legal aid organisation staff and stakeholders also recounted the difficulty of informing victims that they cannot have their cases resolved through family or local justice mechanisms. This can be distressing for those who fear protracted court processes or jail sentences will cause the community to ostracise them or husbands to seek a divorce. Many victims are also said to resent that they have to seek protection with distant relatives or spend up to a year in secure women's shelters while they wait for a hearing. In this sense, the LADV can be interpreted as a top-down imposition of norms and practices that are still struggling to find widespread acceptance in Timor-Leste. ${ }^{82}$ Indeed the difficulties for women caught between their basic needs, culture and the requirements of the law were summed up by a staff member at a women's shelter; "victims become victims of the law". 83

Despite the new law's reporting and case handling obligations, interviews also revealed that legal aid lawyers and paralegals often play a role in the eventual resolution of cases. Specifically they assist clients to submit reconciliation letters to judges, which use them to justify a suspended sentence or a fine, allowing the offender to return to his family. Suspension is granted on a conditional basis, which typically involves disputants performing a reconciliation ceremony to which local authorities are invited, the perpetrator promises to change and gifts are exchanged. Afterwards the legal aid lawyer or paralegal will often assist the couple to draft a letter explaining the terms of the reconciliation agreement to the court. This letter is signed by all involved parties, including the couple's extended families, local authorities and, sometimes, state actors such as the PNTL or public prosecutors. However, so as to adhere to the LADV, most legal aid lawyers and paralegals stressed that they do not have any involvement in the reconciliation ceremony or sign the letter themselves. Indeed they emphasised that the decision to reconcile had to be taken independently of them.

Although this practice occurred before the LADV, interviewees indicated it was becoming increasingly common in response to the new legislation. Moreover, when pressed as to their understandings of the new law's stipulation that domestic violence cases must be resolved through the courts, participants argued that the submission of a reconciliation letter is a practice encouraged by the wider community. They argued that it is speeds up court rulings and allows husbands and allows income, generating husbands to return to their families. Furthermore, a victims support worker suggested the practice prevents the confusion caused when husbands are detained and sentenced

\footnotetext{
82 Ibid.

83 Interview with Stakeholder, 24 May 2013.
} 
three years after the crime is first reported due to court backlogs. ${ }^{84}$ It was also reasoned that both male and female Timorese's understandings of domestic violence do not include verbal abuse or slaps. As a result the shame of incarceration for such offences can lead to divorce, leaving dependent women and children in difficult circumstances. Some even suggested that the practice of submitting reconciliation letters would not be so popular if the LADV had been gradually introduced or local authorities were allowed to resolve less serious cases, defined as those that do not involve 'blood. 85

Many legal aid lawyers and paralegals reported working to address some of the obvious pitfalls of this practice. Firstly, some take the time to investigate the circumstances in which the decision to reconcile is taken. This includes "counselling" clients through the process and explaining the potential outcomes. Secondly, many described adopting a monitoring role following suspended sentences. Although difficult, this involves checking in with the victim and suco authorities to see if the offender is adhering to the sentence's conditions. They argued that the state does not have the information on cases, the resources or the accountability necessary to do this. Lastly, some reported that they explain to communities the meaning of the suspended sentence. This encourages community members to monitor the perpetrator and prevents the common misconception that the court has dismissed cases as local or family matters.

It is arguable that the practice of submitting reconciliation letters allows customary social norms (in the form of reconciliation) to enter into the court's decision-making process and affords victims some measure of agency. Furthermore, the various checks and balances legal aid organisations have designed to protect clients pursuing this course of justice make it difficult to dismiss as illiberal or a residual practice harking back to some ideal era of patriarchy. Rather the method through which local authorities, legal aid organisation staff and state officials work together to facilitate this practice allows it to be interpreted as a locally owned practical hybrid. Indeed it involves the adaptation of, and interactions between, customary social norms and imported notions of justice, and can be seen as a reaction to top-down legislation created by a distant and weak state. Whether this practice will continue as the state strengthens its justice institutions and the LADV is further socialised, is for the foreseeable future, unknown. What is important now is that it is providing a path to justice for victims of domestic violence.

84 Interview with Stakeholder, 24 May 2013.

85 Interview with FECM staff, 20 May 2013. This idea was also voiced by a number of other stakeholders. 
While debates over the use of concepts such as hybridity continue, this paper has argued that Timor-Leste's legal aid lawyers and paralegals are devising practical hybrids to provide access to justice to victims of domestic violence. Well-intentioned programmers are left with the challenge of responding to such practices, particularly important as the state is unlikely to build an adequate formal justice system anytime soon.

A recent edited volume examining seven interventions designed to improve legal empowerment in conflict affected regions concludes that there are few transferable principles for those working across different contexts. ${ }^{86}$ It argues that what may have some measure of success in one context is "situationspecific and contingent on a variety of factors, including social norms, the presence and strength of a rule of law culture, socio-economic realities, and national and geo-politics, among others" ${ }^{87}$ Faced with such challenges, programmers are urged to develop in-depth knowledge of the contexts in which they operate, including an understanding of the actors, interests and institutions shaping the justice landscape. Such knowledge can help them identify and negotiate entry points for interventions that start rights-based discussions, improve access to justice and impact upon the ability of people to take control of their own lives.

At the same time, those advocating an arm's length approach to development doubt outsiders' ability to fully grasp the complexities of the contexts in which they work and suggest they should support, or create the conditions for, solutions devised by local actors. Yet such an approach does not stand at odds with calls for in-depth knowledge of local contexts or the hybridity literatures' focus on the interactions between societies, states and interveners; it demands it. Indeed for those seeking to engage with practical hybrids it is vital to acknowledge that they often evolve to address everyday needs, including context-specific cultural, socio-economic and political considerations. Thus while Timor-Leste's legal aid lawyers and paralegals facilitation of reconciliation letters' submissions to courts breaks the spirit of the LADV, this practice has arisen to negotiate a dual tension - the desire to keep families together and stop violence and the legal requirement to access an emerging liberal state justice system that is largely unable to address women's dependency on their abusers and their families. Furthermore, its proponents are institutionalising a practice that combines local understandings of reconciliation with the state's

\footnotetext{
86 Harper, supra note $5^{8}$.

$87 \quad$ Ibid., p. 173 .
} 
drive to protect victims of domestic violence and bring cases out of the private realm. Indeed the practice should not be taken as a sign that the LADV is unworkable, rather it is an effort to accord an impractical law and imbue it with a measure of local legitimacy. In this sense the submission of reconciliation letters may be seen as a continuation of the Timorese's history of adapting to and coping with the demands of top-down governance.

Understanding the context and rationale for such practices can allow outsiders to devise programmes that build on local solutions. For example, many legal aid lawyers and paralegals argued that before they help couples submit reconciliation letters to the courts they try to ascertain whether ceremonies are performed under coercion. Nonetheless this was outside of their normal scope of activities and not in the programmes mandate. Although difficult, supporting legal aid organisation staff to carry out such roles could provide additional checks and balances to practices that often take place with little oversight. Indeed, rather than avoiding reconciliation ceremonies for fear of being accused of resolving a crime outside of court, legal aid lawyers and paralegals could be encouraged to attend in a monitoring role. Limits could also be set on the number of counselling sessions they or other stakeholders complete with victims of domestic violence before help with the submission of reconciliation letters to judges is offered. Furthermore the involvement of numerous local authorities, including the PNTL, in the signing of reconciliation letters could also be encouraged, thereby, further brining domestic violence into the public sphere. Through such methods, outsiders can work to protect the vulnerable and create the space for adaptations of existing practices that may move them towards human rights standards. Crucially such methods do not assume that interveners are best placed to develop hierarchies of norms or are that they are able to control the long run direction of social change. Instead they would acknowledge the agency and resilience of local actors, and support the coping strategies of populations caught in difficult circumstances. 